\title{
The over-familiar landscape that escapes to the absent-minded gaze
}

\section{Marco Mareggi}

Politecnico di Milano, Italy

Department of Architecture and Urban Studies

marco.mareggi@polimi.it

\begin{abstract}
Public spaces constitute a relevant part of the landscape of the ordinary city. According to the European Landscape Convention, studies and designs of public spaces, in particular of open spaces, should appropriately focus on the different users who inhabit it and recognise themselves in these spaces. In this sense, close to the traditional studies on morphological characteristics, urban materials and equipment, it is useful to explore the performances of public spaces in innovative ways. This article proposes to come back to emphasise and highlight daily life, still today forgotten as a relevant component of a good design and planning of public spaces. It underlines the importance of the gaze on the everyday and ordinary for urbanism, through some introductory experiences of designed urban spaces and some concepts, such as 'practices' and 'way of uses'. Moreover, it offers a review of different lines of studies on public life and other research interested in daily urban practices. Among these, the article focuses on rhythm and chronographic analysis, which describe practices of use, urban populations and their rhythms of presence within places. In conclusion are presented some opportunities that an adoption of the proposed approaches to everyday could bring to a better management, maintenance and planning of public spaces.
\end{abstract}

Keywords: everyday life; urban rhythms; practices of uses; ordinary city; public life; phenomenological approach.

\section{To cite this article:}

Mareggi, M. (2017). The over-familiar landscape that escapes to the absent-minded gaze, The Journal of Public Space, 2(I), 109-I22, DOI: 10.5204/jps.v2il.54

This article has been peer-reviewed and accepted for publication in The Journal of Public Space. Please see the Editorial Policies under the 'About' section of the journal website for further information. 


\section{Starting from daily life}

In everyday life, the configuration of spaces and the practices of use are often unexpected and interwoven.

In order to explain this relation two different public open spaces are here presented. They are geographically very far but associated by a complex and interesting relationship between the design of physical spaces and their everyday use. Within these two open spaces the morphology of the ground and the design of the equipment play a fundamental role in the (designed and unexpected) use made by inhabitants in their daily routines and free time.

These two cases allow us to look at everyday life. As a matter of fact, according to Ralph Erskine "the so useful art of architecture achieves its greatest potential when it is most beautifully attuned not only to spectacular special needs but also to the undramatic and even intimate everyday needs of people when they are functioning individually or in groups. ... It is the everyday situations that are important and that shape the major part of our lives and cities" (Erskine, 1986: 7).

Walking toward the Station: when the project of the ground goes along with practices Piacenza is an Italian city in Po Valley; it hosts two small universities. Few years ago, the municipality has promoted a redevelopment of the square in front of the train station. The project gave priority to pedestrian in the space going from the rails to the urban park, going through the square and a main street (thanks to a movement of the ground and the use of a different material) and giving a new use to an old pedestrian underpass, with escalators. Without breaking or fragmenting materials and walkways, the "project of the ground" (Secchi, 1986) considers more important the pedestrian flows to and from the station, emphasizing both the feeling of continuity and the pedestrian movement; and creating two different ways to cross the street. Taking into account the numerous people crossing the street to reach the train station on the rush hour is a clear design choice. This choice improves the liveability of an intermodal urban hub: it promotes sustainable mobility and promenades before car use. The everyday practices of this place reinforce the project: people choose to walk almost every time at the street level, without even using the underpass. In order to reduce this practice, improving the use of the underpass and reducing the presence of pedestrian on the street, the Municipality decided to install a barrier all along the street, denying the idea of a physical and perceptive continuity. Since this decision was taken, pedestrians have started to cross the street toward the Station despite the new physical barrier and to move freely until today (Fig. I).

Plunge into water: when equipment offers new uses

Turilandia and Santa Helena are two towns on the North-East of Brazil, stretched along the two opposite riversides of the Rio Turiçú. The two municipalities have interpreted in different ways the relation to the river, which is close to a bridge connecting the two cities. In the first case there is a green area bounded along the river by a wall allowing to sit, reach and overlook the river. The wall itself set the occasion to plunge into the muddy water, having fun and showing-off. In the second case the municipality design an urban street, Avenida Beira de Rio. This street connects the church square, which is facing the river through a small mooring and a gazebo, with some detached houses. The street goes under the bridge deck, occupied by some huts, such as small commerce and meeting points. The avenida has a stone central flowerbed and large sidewalks; a light handrail with wooden bench divides it from the river. The handrail and the beams of the 
bridges become a springboard. The street and the bottom of the bridge, instead of being urban fringes, are spaces for social life: shaded by the bridge, some young people spend time to relax, also showing them off during the tropical heat. The bench along the river became a meeting point. Also, the square hosts the stops of the motorcycles and their banquets thanks to a gazebo. Two moments of leisure partially designed and partially unattended, both encouraged by the morphology of the places, face each other on the two riversides in the meadow and along the street (Fig. 2).
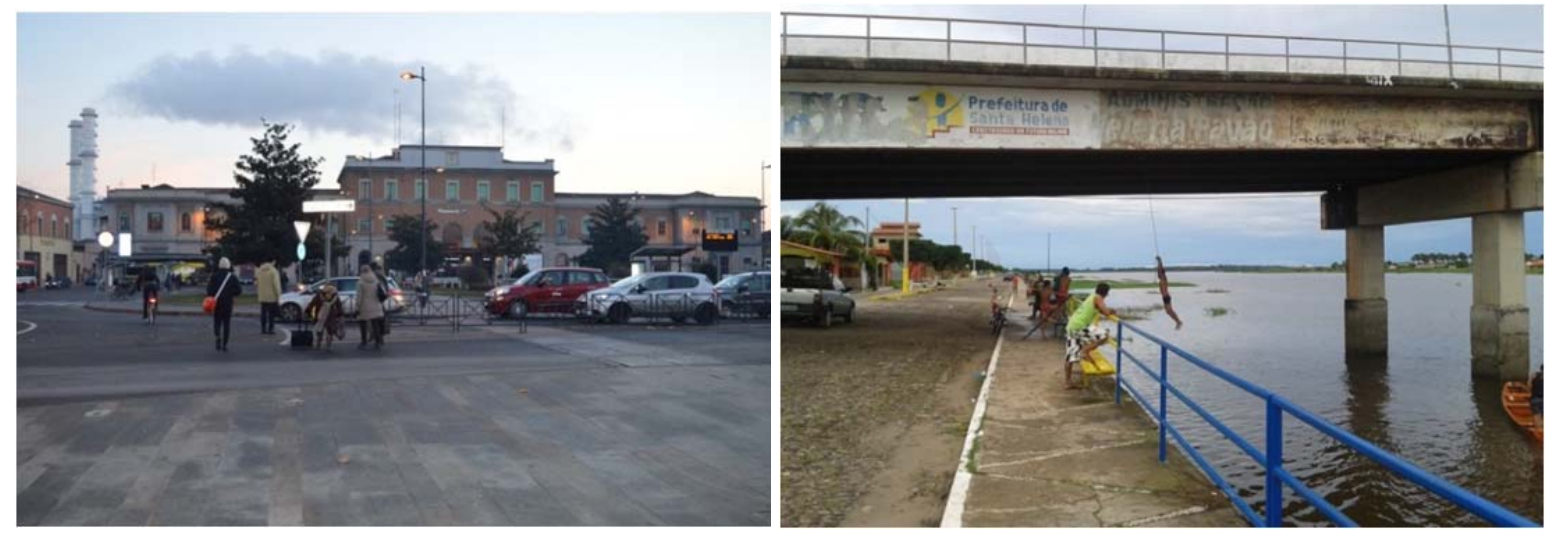

Fig. I (on the left). Piacenza (Italy). January 9, 2017. h. 8:08 During rush hours, the commuters cross the street from the Station despite the physical barrier.

Fig. 2 (on the right). Santa Helena (Maranhao, Brazil). April 18, 20I4. h. 14:42. In the sultry afternoon, the young people are discovering the new uses of the riverside street, such as plunging into water.

The two examples have some common aspects. Regarding the spatial solutions, they are the result of an intentional re-design of public space (ground, equipment and connections) and, after these interventions; they show that the practices of uses of the spaces in some moments can offer other perspectives of the proposed solutions. Methodologically, both cases demonstrate the need to combine the space and the practices of uses in daily life, for seeing and understanding their functioning and potentialities in social - individual and group - uses. Recognising specific practices and rhythms of uses in everyday life means to identify repetitions and discontinuities that generate sociality, because every social relationships - such as looking, speaking, meeting, having fun and etc. - are always space and time rooted. Nevertheless, looking at spatial-temporal practices allows observing also that in some moments human behaviours do not respect the order gave by the space; and the practices of uses superimpose a new dynamic of uses. So, the descriptions of the two different experiences underline the opportunity to pay attention to what is over-familiar, to what happens in the routines and in daily life, as useful methodology to understand how the collective space works in order to transform or maintain its suitably.

\section{Open spaces as a stage for public practices}

The observation of everyday life gives an interesting point of view to better understand the processes of open spaces as urban stages. From one side, this observation can become an important tool to understand urban changes and to define the questions undergoing these transformations (Bianchetti, 2003). On the other hand, and more importantly for urban design, it offers interesting elements of analysis even if not always taken into account in the design of places. As a matter of fact, this point of view is a way 
to modify and enrich the design process trying to "be closer to things and people" (Benvenuto, 1989); and thus, even more today, it can be a tool for urban design, keeping in mind that the transformations are gradually less the product of deeply living a place. When I talk about practices, I refer to the ways in which a city is inhabited, lived, experienced and transformed by its own inhabitants (Cellamare, 2008: 122); practices are "the collective, recurring and repetitive ways of doing (...) what people do intentionally. Without thinking about it, because you did it already like that and this is the way to do it, because everybody does it in this way (...) they are not isolated actions, neither combined (...) it is not a joint action" (Crosta, 2007: 87). Looking at places from the point of view of practices offers a vision from the inside, useful for the design, that complements more traditional point of views both from the top (using maps) and from the bottom (making field trips and visual observations). Moreover, it tries to understand how different persons live their context and it includes into the analysis contemporary multi-scalar ways of inhabiting places.

Starting from the practices means, then, to assume the inhabitants' point of view and to renew the attention toward the ways of use of the territory. As Patrizia Gabellini suggests, "the ways of use represent the relationship among populations, places and times". They represent "how people use different urban spaces, diverse facilities, and how spaces are used by diverse metropolitan populations", without forgetting the priority of town planning given the strong relationship between physical characterisation and anthropic behaviours. In fact, "space features (urban materials and functioning) influence practices (ways of use), but they do not determine them" and "the ways of use can have a repercussion on the facilities and their performances. There is always a gap among facilities, their performances and effective ways of use" (Gabellini, 20I0). In this article I argue that staying closer to people and things (like, for example, starting from the uses of physical spaces where facilities and the related utilisation are tested) means to propose a specific view on the territory. Such unconventional point of view implies that both descriptions and design of public policies focus on, and then affect, the "lived space", not the "perceived" or the "conceived" space (Soja, 1996: 74; Simeoforidis, 2002: 150). According to this perspective, time becomes an instrument to understand the lived space and vice versa.

Also studies and designs of public spaces, in particular of open spaces - that are a relevant part of the landscape of the ordinary city - could appropriately focus on the different users inhabiting it and recognising themselves in these spaces, as stated by the European Landscape Convention (2000). According to the European Landscape Convention, the landscape does not exist without people and society creating and recognising its identity. Accordingly, near to the traditional studies on morphological characteristics and on the amount of urban materials and equipment, it is useful to explore the performances of public spaces in innovative ways. The proposed approach invites us to increasingly refer to territorial practices and rhythms of use, that is a way to emphasise and highlight everyday life and ordinary city, not only by describing it but also through design and plan. Therefore, the article proposes to researchers and design professionals to focus again on the everyday, which has connoted all the 20th century (Secchi, 1999: 57), but has had not relevant effects on ordinary planning and design of our cities. Indeed, still today, the design of public open spaces frequently remains sectoral, such as actions on mobility or beautification, and uninterested to individual daily life and social behaviours in public spaces. Starting from these, the article draws from the Italian and international contexts both practices and literature. 
On one hand, the article aims at reflecting on the everyday as what is over-familiar in our urban landscapes and as what escapes to the absent-minded gaze. The introductive examples, result of visual observations, and concepts such as practices and ways of use, coming from literature, underline the importance of the everyday gaze for urban planning and design and of reaffirming the role of public spaces as stages for urban practices, both collective and individual.

On the other hand, the article aims at exploring what kind of approaches and tools have been developed in the last decades to ameliorate the interest on daily life in public spaces. Through a literature survey (urban planning and design, sociology and some encroachment in anthropology and geography), the next paragraph offers a review of the different lines of studies on public life and research on practices in open spaces and their diversifications in time schedules of uses. The following paragraph presents, in a tendentious way, the spatial-temporal approach developed by the Italian school of Politecnico di Milano, through a synthetic report of different European experiences and tools employed in research, public policies and didactical urban design workshops. The work ends with a reflection on the improvement in the toolkit for the rhythm analysis from Seventies on, and remarks the opportunities that the adoption of the different approaches proposed in the everyday and ordinary could bring to a better management, maintenance and planning of public spaces.

\section{Different conjugations and approaches}

Considering everyday urban practices, both in their recurrent patterns and for their extraordinary variety and vitality mean "grasping a phenomenology that cannot be known through theory or cognition alone" (Amin and Thrift, 2002: 9). Several lines of research have approached to this issue, some of which refer specifically to public open spaces. Sociology has gone deeper into the analysis of social behaviours and, thanks to the time budgets, has put a focus on the temporal dynamics of individuals at a quantitative level (Gershuny, 1999). In the last twenty years, this branch of investigation has built up a body of studies to measure the quantity of "average time" that people employ in different activities. Nowadays, comparative data (Eurostat) and studies are available for many European cities; yet, if on one hand these studies are effective to show the different average time availabilities of individuals at a macro urban level, and to draw profiles of time uses at overall scale; on the other hand, they are difficult to use within the design processes of specific places, either physical than social, because these data are only available in aggregate forms.

Another urban sociology's specific branch further explored the issue of practices related to time, starting from the concept of populations. The interest originates from a reflection about the divergence between the shrinking population of the metropolis, reported and measured by institutions, and the widespread perception of congestion and overcrowding of people in cities, for large segments of time. Guido Martinotti (1993) and his school (Nuvolati, 2003) have observed and delivered a classification of populations in relation to their temporary presence in places, and to the reasons of this presence: commuters, daily and weekly city users, seasonal tourists, businessman/woman, flàneurs and immigrants. This branch of studies, especially in Italy, has influenced the capacity of observing places starting from the presence of populations who inhabit and use the city and its services, thus taking into account opportunities and conflicts generated by the cohabitation of different populations during a given period of time. This approach began 
to be influential also on planning instruments at different scales, both in cities and regions where temporary living dwelling of places is significant but underestimated, or used in restricted sectorial context such as university cities, seasonal tourist destinations or nightlife areas.

More recent studies (Pasqui, 2008) have proposed an analysis of populations inhabiting the city precisely for specific practices happening there, in order to address more effectively urban policies and planning. Analysis and description of these populations still represent an open question, mostly developed in reference to urban mobility, through the innovative use of phone data (Ratti et al., 2006; Pulselli and Romano, 2009; Pucci, Manfredini and Tagliolato, 20I5).

In urbanism, following a different path, Anglo-American approaches favour phenomenological descriptions of what happens in the public space, with an interest in spontaneous and informal uses as a key passage to realize an "everyday urbanism" (Leighton Chase, Crawford and Kaliski, 1999). The analysis of the temporary use of public spaces and of social behaviours in the real life and daily routines, or in other words, the social practices in public spaces, mostly open spaces, gives back a variety of activities, both dynamic and sedentary such as: informal commerce, recreational activities (for few minutes or for many hours, at a given hours or more spontaneously), production (in neglected spaces, or in community garden), celebrations or expressions of dissent, legal and temporary reuse of abandoned urban plots for common uses, urban grazing to take care of large public park, or, in some cases, temporary houses in urban fringe (Frank, 2012). If, on one hand, these activities reveal a non-permanent city, on the other side, to some urban planners, such as Margaret Crawford, they open-up new directions for urban planning, suggesting an incremental approach, that works with small changes collected until transforming big urban contexts. The action is made of small and temporary steps, whit particular attention with the respect to rules and their application, with the activation of processes socially and (in part) economically sustainable for public-private management of collective spaces. In such a discreet way the professional boundary of architects and urban planners has been overcome. Thus, they are responsible also for the management of space beyond its material transformation and they cover expertise regarding life in public space and spontaneous city.

In this direction sociologists, urban planners and journalists such as Jane Jacobs (1961) and William Whyte (1980), thanks to their anthropological and polyhedral attention to social life of urban spaces, have given a very relevant contribution to the debate.

Other schools of architecture and planning - particularly the Danish school of architecture and planning and a long tradition of North European (i.e. Ralph Erskine but also Giancarlo De Carlo) and North American urban studies (i.e. Kevin Lynch and Christopher Alexander) - re-read and design the "life between buildings" (Gehl, 1980). Following the effort to realize better environmental conditions, they observe, while happening, everyday phenomenology. This methodology of structured observation (differentiated analysis based on users, perception and appreciation; field trips as well as explanatory and focused use of photography; morphological analysis of public spaces as places for social and cultural exchange) and representation (such as through maps of people's behaviours, traces and diaries) (Fig. 3) works with specialised disciplines, such as sociology and psychology, to use sensorial factors (visual or sounds), mental reactions and people behaviours in open spaces in the city design. 

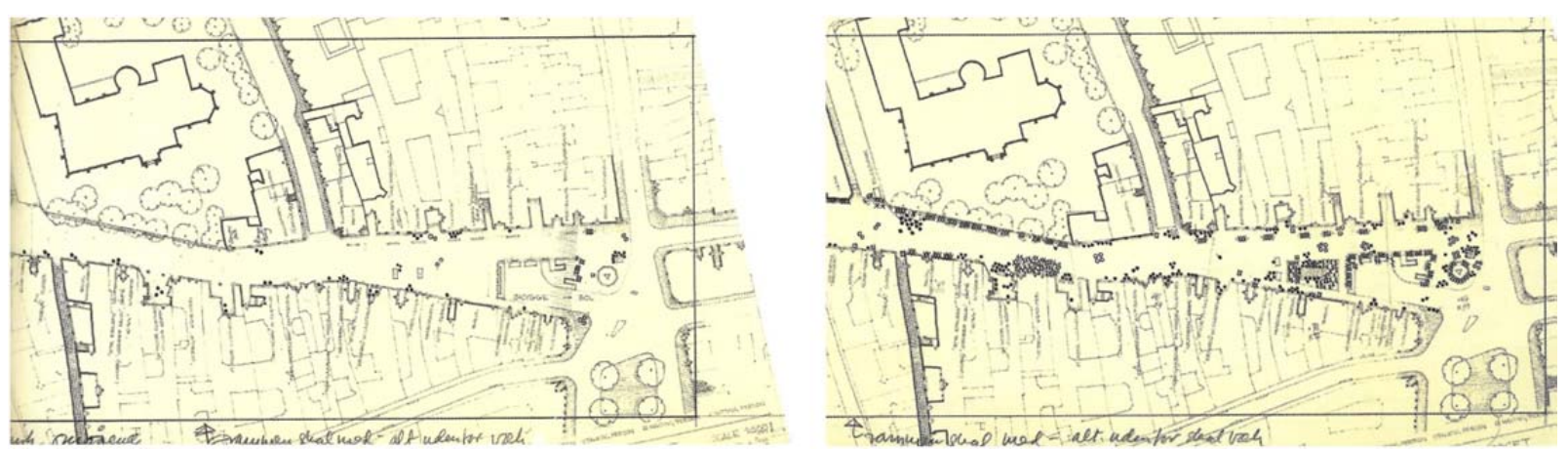

Fig. 3. Map of people's behaviours (standing and sitting) in outdoor spaces in different seasons: winter (on the right) and summer (on the left). Source: (Gehl, 1968).

Completely different efforts have been made by studies on diffused and sprawled city. They have put a stress on attentive observation of space in relation to social types. This point of view is related specifically to physical urban materials. It reclaims the tradition of morphological analysis considering it in more innovative ways. Researchers, planners and architects aims to discover, without detriments, the characteristics of the urban environment of contemporary cities, making important efforts to discover new housing phenomena, social and physical, and to highlight their territorial effects. The focus of this research is not the open space but the combination between urban materials and new consumption and life styles. Most of these studies describe new relational geographies between places and peoples. This approach, quite different from the others presented, proposes an analytical interest of the spatial and social phenomenology. In Italy and Europe, it has been developed in the Nineties (Indovina, 1990; Boeri, Lanzani and Marini, 1993; Secchi, 1994; Munarin and Tosi, 200I). Moreover, it has introduced an interesting perspective for the design of public spaces, regarding the "project of the ground" and the re-enhancement of the "welfare space". The "project of the ground" (Secchi, 1986, 2006) proposes the redefinition of the architecture of the "level zero" of the soil (Aymonino and Mosco, 2006) and it considers the continuity of the ground ensuring the needed connexions of the public city. Instead, the "welfare space" remarks the importance to rethink the physical component of public services, equipment and social-collective spaces useful to guarantee comfort, safety and wellbeing (Munarin and Tosi, 2009; Officina Welfare Space, 20I2). These have guided diverse projects and realisations in European cities.

Lastly, rhythm and chronographic analyses of the Italian school emphasise the changing characters of the city. These works study the territory "from the bottom and from inside", starting from different time schedules of services and temporalities in the use of places, in order to understand who are the inhabitants, what are the activities they perform in the cities and when they happen, in relation to both private/public activities and open spaces. This point of view takes into account temporary and resident populations, mobile and permanent ones, or populations related to practices: the rhythm (duration and recurrence) characterises their physical presence into spaces. In this way the different and layered time of use shows vibrant lived spaces. The time-geographers of the Swedish School of Lund, starting from the studies of Torsten Hägerstrand in the Seventies (Carlstein, Parkes and Thrift, 1978), have been pioneers to reconnect individual behaviours in space and time. Also Kevin Lynch (1972) conducted an interpretative and 
advanced research to recognise spatial and temporal aspects of urban planning. In the Nineties, the School of Architecture and Society of Politecnico di Milano has developed and applied this approach to specific public policies and planning experiences (urban time policies), and it has tried to introduce it in the urban design domain, unfortunately with scarce results. It has been developed in different planning tools of Italian cities and in very few European cases (Bonfiglioli and Mareggi, 1997; Mareggi, 20I I, 2012; Henkel et al, 2012). The following paragraph illustrates the ways to describe the space-time characteristics of open spaces.

The knowledge of practices and rhythms of uses contributes to investigate and to focus the project on performances and physical sensitiveness (in particular on space and time's measures of different human bodies). Furthermore, together with the previously proposed approaches, it brings into play a displacement of traditional architectural and urban analyses, just looking at places' character and consistency.

This overview of different variations and approaches to open space raise three issues. First of all, the presented review is a research domain mixing different disciplines and being at their intersections, even though a forceful contamination is very difficult to obtain. Secondly, these studies are offering valuable instruments for research and design, answering to instances also underlined by studies on the quality of life. These studies assert that territorial allocation and performance are not the only factors to consider when dealing with goods and services; what is important is their usability, what can be done (functioning) choosing among possible alternatives (capabilities) (Sen, 1993, cited by Nuvolati, 2007: 106). Urban quality is not only determined by physical conditions and supply of services, but also by the uses and conditions of use of the different subjects/users. Moreover, the interest in these studies is not only focused on spontaneous, informal and unauthorised uses of spaces, highlighting unexpressed needs unable to find answers in a given context of space and services allocation. On the contrary, the focus is oriented on simple and recurrent everyday activities (De Certeau, 1990), which is all what happens, which is over-familiar and common and which we perceive it without paying attention. These last issues are often neglected within the social and physical design of public open spaces.

\section{For a study on territorial practices and rhythms of use}

Practices and rhythms of use of public open spaces of the ordinary city are investigated in some experiences and tools employed in research, public policies and didactic urban design workshops. Some Italian municipalities have developed: chronographic maps with opening time schedules of public activities in all municipal area (Comune di Bergamo, 2006; Città di Bolzano, 2009) and with time schedules of prevalent use of open and collective spaces; maps of usability and accessibility of green spaces, as in Paderno Dugnano, or of open spaces in Rozzano (Mareggi, 20I2); space-time studies on liveability of neighbourhood's square in Pesaro (Comune di Pesaro, 1999) (Fig. 4) and chronographic maps of circuits of frequentation of population in central urban areas such as in Busto Arsizio (Brioschi, 1997), Cremona (Comune di Cremona, 1999), Cologno Monzese (Zanettichini, 20I I) or Gallarate (Mareggi, 20I I). Maps of the use intensity of places are available for some coastal areas with significant tourist attraction such as in the Apulia Region (Mininni, 20I0). Similar exercises have been carried out with students in the Urban planning studios at the School of Architecture and Society, Politecnico di 
Milano (Longo and Mareggi, 20I2; Mareggi and Pucci, 20I3), for which it has been prepared the following methodological note.
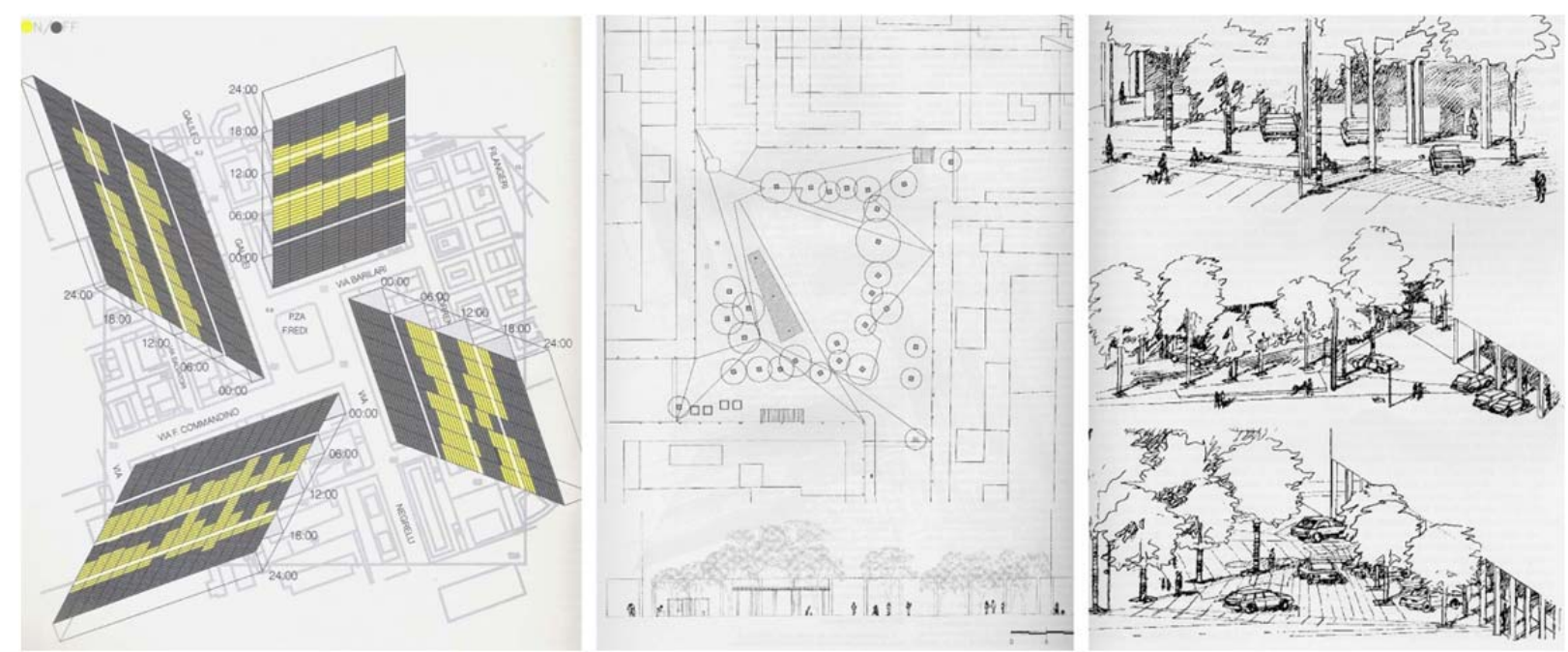

Fig. 4. Space-time studies and intervention of a neighbourhood's square in Pesaro (Italy): opening calendar of commerce and services (on the left), project (in the middle) and sketches (on the right).

Source: (Comune di Pesaro, 1999).

Specifically, during the phases of analysis and description, parallel to the design activities, the identification of who inhabits the considered places, when and in which way, is it accompanied by a morphological investigation of the context and the sites of intervention, by the re-enactment of the main historical and geographical characteristics of the territory.

The component of "who, when, whom" - together with forms and functions' analysis realised through on site surveys - enriches the bird's eye view of the city, based on the maps, with a bottom-up approach, looking at the context from inside and "being closer to things and people". More in detail, the observation and the exercises of description and design have been focused also on ways and rhythms of use of the territory.

The ways of use allow us to read social practices produced by the different populations in a given space. They show how people use and experience public spaces and services, and how spaces are used, perceived and transformed by different populations inhabiting and visiting the territory. The ways of use describe the relationships among populations, places, and times. Typical ways of use allow identification of specific urban landscapes. During the design process, to analyse and be aware of the ways we inhabit the places helps the designer to consider at the same time the users and their ways of use of spaces; furthermore, it enables to compare the physical features of a place with the real possibilities and constraints of urban materials, allowing or preventing everyday practices. All these can help the designer to underline potentialities and to re-signify spaces.

The rhythms of use, instead, aim to emphasise the temporal components characterising continuous presence, temporary frequentations and recurrence in the use of places by different subjects. The urban rhythm analysis focuses on three aspects. First, different populations inhabiting the territories are observed and analysed in relation to their continuous or temporary presence in a given place (residents, commuters, city users, tourists), in relation with different ages and periods of life (i.e. child, boys and girls, young 
people, young couple with children, elderly, grandparents with grandchildren and others) or in relation with specific practices of uses (for example, cyclists, motorcyclists, hikers, aggregates loaders, campers, bathers, canoeists, card players, skaters). Second, the located functions are specified with respect to schedules, calendars, opening/closing hours and their character of "obliged time schedule" of a territory (prevailing work activities as well as school hours), or because they can be chosen by the inhabitants (i.e. sports, cultural and entertainment equipment, commercial distribution, natural parks, thematic paths, events). Finally, the mobility network is investigated with respect to public transport timetables, flows of traffic, various forms and intensity of movements and rests, even walking and cycling, perceptions and distances in terms of time. This last element redesigns geographies of changing space-time relations, site-specific, and shows interesting potential connections for the project.
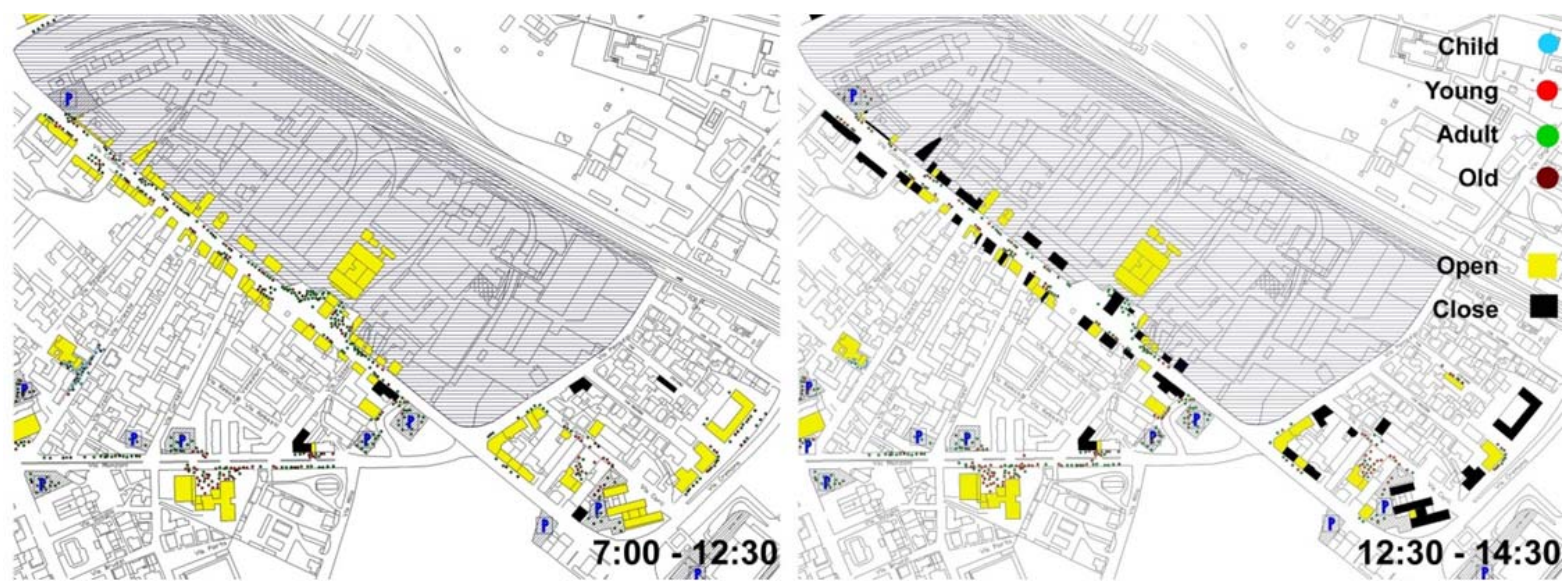

Fig. 5. Chronographic map of frequentation circuits of populations (different ages) around Emilia Street in Piacenza (Italy) in different moments: morning (on the left) and mid-day (on the right) of a working day. Source: (D. Casaroli, B. Siero, Politecnico di Milano, Piacenza Campus, 2008).

Thus, the description of practices and rhythms of use of open spaces implies to:

- Observation of those who frequents the places, which kind of activities they perform and in which moments, and, at the same time, to indicate the places, the circuits and the moments of higher/lower presence and density of use. These observation, based on site surveys and information collected with interviews and stories, are often complemented by official data such as resident population, commuters and overnight stays in tourist accommodation. In didactic exercises, sometimes population profiles with typical behaviours are drawn through maps, timetables and photos;

- Detection of functions and time schedules of public or collective services (and, in some cases, the workplaces) and time schedules of activities taking place in public spaces (both planned or informal). Information was obtained through survey of time schedules and direct visual observation of the practices of use in their real occurrence. These on site surveys need to be realised in different moments of the day/seasons or information can be collected through the inhabitants and visitors' stories or interviews. Among these functions, the identification of the 'attractors' is particularly interesting: when there is a presence and distribution of services and functions that attract or may attract a relevant number of people, according to their schedules and calendars of opening hours; 
- Specifying the main aspects of mobility, also pedestrian and bicycle, which are relevant in relation to project issues. These data are a collection of statistical information (such as origin-destination of workers and students), social surveys on mobility behaviours, stories of different typical mobility profiles, and mapped and counted individual behaviours (frequentation circuits of populations) through visual observation in different temporal phases (Fig. 5).

Usually, chronographic (also dynamic) maps, calendars (hourly, daily, weekly, seasonal, annual, long-term or occasional) and pictures are ways to present the synthetic description of the ways and rhythms of use of spaces (Fig. 6). They show the phenomenology of everyday life in the investigated open spaces. These representations often reveal opportunities, demands and implicit desires, expressed through the either recurrent or occasional actions of the different inhabitants.

These explorations of lived space enable the project of public spaces to: question directly the main subject who is the receiver of the transformative action; evaluate the different possibilities of use; articulate urban materials and levels of comfort; make readable and manageable the coexistence of potentially conflicting uses and populations; integrate in the design and planning physical interventions and policies for the space-time management.

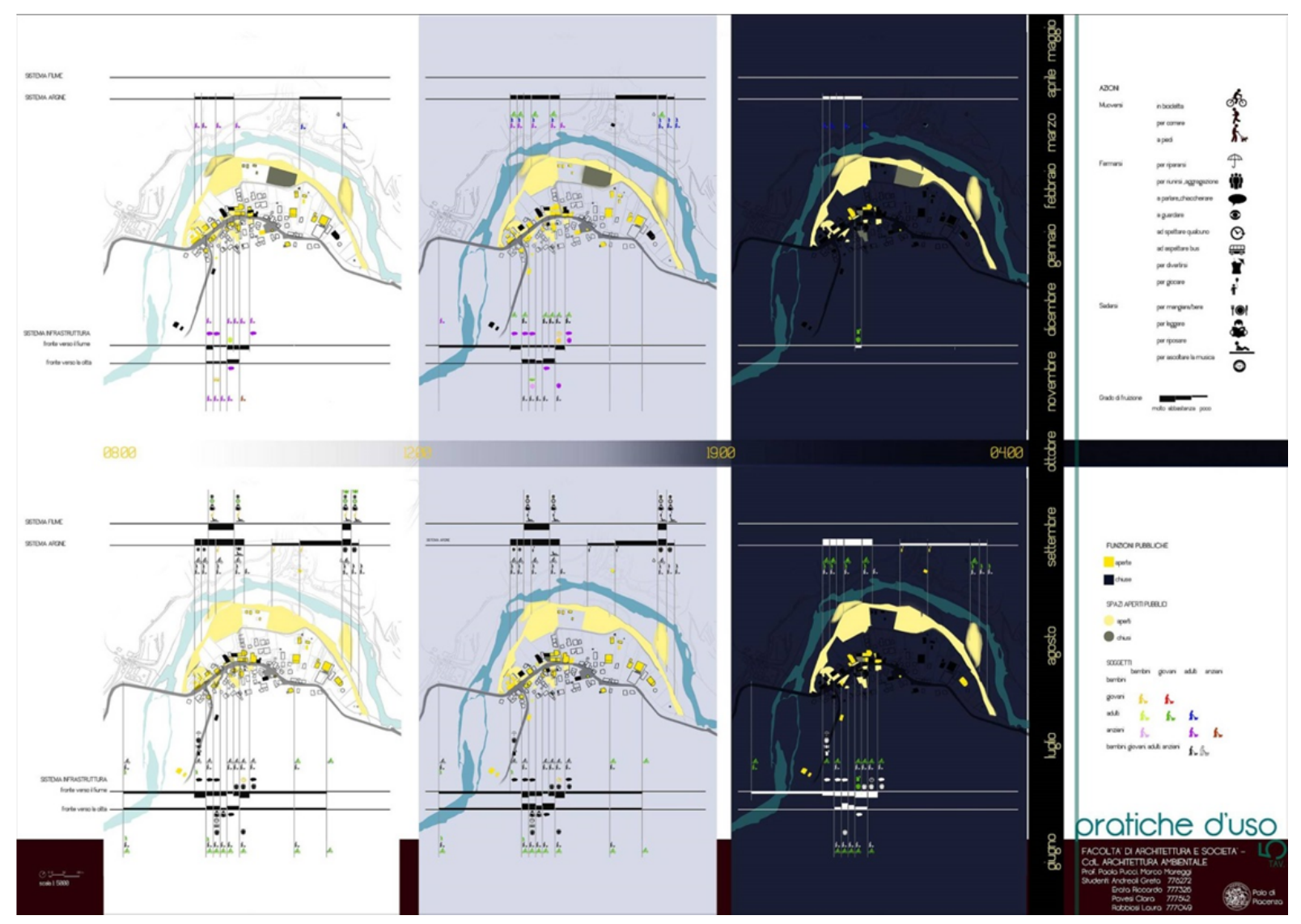

Fig. 6. Rhythms and practices of uses (populations of different ages moving, staying and sitting) and openedclosed activities (yellow-black) along the river Trebbia in a little village (Marsaglia, Italy) in different seasons (low season, top; high season, bottom) and in diverse daily intervals: morning (white background), afternoon (grey background) and night (dark background). Source: (Mareggi, Pucci, 20I3). 


\section{To consolidate the analysis and to ameliorate the design out-put}

The attention to everyday life on the analysis of open spaces has started to consolidate in many different academic domains, even if still not central in the architectural and urban debate. The actions produced by public administrations seem to be less strong, even though they are slowly emerging.

As shown in the brief review proposed, about research, near to traditional studies on morphological characteristics and on the amount of urban materials and equipment, simple and effective techniques and some innovations seem reinforced. By now, they are useful both to recognise new shapes of contemporary city, and territorial practices and rhythms of use. Research on the latter is not yet widespread. And it is difficult to trace experiences in which different approaches can interact or dialogue together.

Regarding territorial practices and rhythms of use, in the Seventies, from a theoretical point of view, Henry Lefebvre (2004) suggested rhythm analysis as an original way to get closer to familiar phenomena, more a (re)orientation than a method for the studies on daily life. More recently, Ash Amin and Nigel Thrift underlined that "there are no clear methods for rhythm analysis, only other metaphors" (Amin and Thrift, 2002: 19). Today we are beginning to give technically relevant answers to the shortage of tool for the rhythm analysis, although hourly data are difficult to obtain and continuously variable. The tools for descriptions of ways and rhythms of uses focus on lived landscape of the ordinary city, the over-familiar landscape that escapes to the absent-minded gaze. These methods offer to planning and architectural projects (but also to the definition of public policies) tools to deal with the demands of care and habitability coming from different urban populations with different schedules and calendars, largely unheeded in urban expansions and in the management and maintenance of the public and private open spaces of existing cities.

These small innovations together with the recovering of traditions, which are still peripheral on the disciplinary debate, are an important occasion not for the design of extraordinary spaces of governmental representation, but for conceiving everyday contemporary urban spaces such as: squares, streets, parking lots, sport fields and playgrounds, as well as in-between spaces, spaces that are passing through an uncertain and changing status, landlocked agricultural plots, urban and countryside paths. More than 20 years ago Vittorio Gregotti (1993), together with other scholars, already put the attention on these spaces as key elements for the project of open spaces; nowadays we could add also the neglected spaces of the historical city, abandoned parts of mono functional zoning, incomplete open spaces of the under construction cities, and many others more. This is the net of ordinary spaces, which build the urban tissue of public life in the decreasing, reducing and shrinking city (Lanzani, 20I2).

Considering the richness of the perspective on daily life and the tools proposed by the different approaches reviewed in this article, can these small innovations be an additional occasion to improve management, maintenance and design of public spaces?

First of all the phenomenological approach, together with the analysis of time schedules data and space-time data, can contribute to renew the design of many and diverse open spaces of contemporary cities, which are the main stage for collective life, making them more appropriate to the real life. Secondly, this plural approach to physical and social aspects obliges to more frequent field trips (generating forms of listening, participation and co-design) and brings to a less standardised and more articulated design and policies for social activities. These should be all elements of a common project, elements that are nowadays still considered separated, except in very few cases. Therefore, this goes over

I 20 | The Journal of Public Space, 2(I), 20I7 | ISSN 2206-9658

(C) Queensland University of Technology 
the sectoral planning of public spaces. Furthermore, this approach can help to transform the competences of technicians and designers, that is not acting anymore only to redesign physical spaces but progressively to contribute to better manage, to adequately maintain and to update the use of open spaces. Moreover, this helps to transform these "spaces inbetween things" in stages and spaces full of meaning and life. Finally, a better dialog, even if not that easy, between different but complementary proposed approaches could enrich both the analysis and the projects, giving more result to this peripheral tradition, aiming to act on ordinary public spaces, which are still the backbone of public life.

\section{References}

Aymonino, A. and Mosco, P.V. (2006) (eds.). Spazi pubblici contemporanei. Architettura a volume zero. Milan: Skira.

Amin, A. and Thrift N. (2002). Cities. Reimagining the urban. Oxford: Blackwell.

Benvenuto, E. (1989). Città e figure del tempo. In Aa.Vv., La città oltre la metropoli (pp. 2I-34). Venice: Università internazionale dell'arte.

Bianchetti, C. (2003). Abitare la città contemporanea. Milan: Skira.

Boeri, S., Lanzani, A. and Marini E. (1993). Il territorio che cambia. Milano: Abitare Segesta - AIM

Bonfiglioli, S. and Mareggi M. (1997) (eds.). "Il tempo e la città fra natura e storia. Atlante di progetti sui tempi della città". In Urbanistica Quaderni. 12.

Brioschi, L. (1997). "Commerce, flows and mobility in Busto Arsizio historical centre". In Urbanistica Quaderni. 12, Pp. 62-67.

Carlstein, T., Parkes, D. and Thrift N. (1978) (eds.). Timing Space and Spacing Time. London: Arnold.

Cellamare, C. (2008). Fare città. Pratiche urbane e storie di luoghi. Milan: Elèuthera.

Città di Bolzano (2009). II Piano dei servizi e le politiche temporali, available at: http://www.comune.bolzano.it/UploadDocs/9224_I_Piano_servizi_ita.pdf; accessed 29 December 2016.

Comune di Bergamo (2006). Piano territoriale degli orari, available at: www.comune.bergamo.it $/$ servizi/Menu/dinamica.aspx?idSezione $=3780 \&$ idArea $=||$ 82\&idCat $=||$ 95\& $\mid$ $\mathrm{D}=$ 1925\&TipoElemento=pagina; accessed 29 December 2016.

Comune di Cremona (1999). Piano dei tempi e degli orari della città di Cremona. La fase di sperimentazione, available at: www.comune.cremona.it/images/comu/varie/I999piano-tempi.pdf; accessed 29 December 2016.

Comune di Pesaro (1999). "II Piano dei tempi e degli orari della città di Pesaro". In Urbanistica Quaderni. 18.

Crosta, P.L. (2007). L'abitare itinerante come 'pratica dell'abitare': che costruisce territori e costruisce popolazioni. Politicità delle pratiche. In A. Balducci, V. Fedeli (eds.), I territori della città in trasformazione (pp. 76-90). Milan: Angeli.

De Certeau, M. (1990). L'invention du quotidien. Paris: Gallimard.

Erskine, R. (1986). Foreword. In J. Gehl (1987), Life between buildings (p. 7). New York: Van Nostrand Reinhold Company.

Frank, K.A. (2012). Il possibile, il diverso e l'inatteso nello spazio pubblico urbano. In A. Bocco (ed.), Qui è ora, Macerata: Quodlibet, pp. 7I-85.

Gabellini, P. (2010). Facilities performances and ways of use, available at: http://www.laboratoriorapu.it/LPU_sito/download/Materiali_Papers/08_2010.04.2I_Facilities\%20pe rformances\%20and\%20ways\%20of\%20use.pdf; accessed 29 December 2016.

Gershuny, I. (1999). "Time budget, life histories and social position". In Quality and quantity. 33 (3), pp. 277-289.

Gehl, J. (1968). “Mennesker til Fods". In Arkitekten. 20, pp. 429-446.

Gehl, J. (1980). Livet mellem husen. Copenhagen: Arkitektens Forlag. English edition: (1987). Life between buildings. New York: Van Nostrand Reinhold.

Gregotti, V. et al. (1993). "The design of open space". In Casabella. 597-598. 
The over-familiar landscape that escapes to the absent-minded gaze

Henkel, D. et al. (2012) (eds.). Space-Time Design of the Public City. London-New York: Springer. Indovina, F. (1990) (ed). La città diffusa, Venice: Daest - luav.

Jacobs, J. (196I). The death and life of great American cities. London: Penguin Books.

Lanzani, A. (20I2). L'urbanizzazione diffusa dopo la stagione della crescita. In C. Papa (ed.), Letture di paesaggi, Milan: Guerini Associati, pp. 223-264.

Lefebvre, H. (2004). Rhythmanalysis. Space, Time and Everyday Life. London-New York: Continuum.

Leighton Chase, J., Crawford, M. and Kaliski J. (1999) (eds.). Everyday Urbanism. New York: The Monacelli Press.

Longo, A. and Mareggi M. (2012). "Learning by design in an international Urban planning and Policy design Master Program”. In Planum. The Journal of Urbanism. 25 (2): I- I5, available at: www.planum.net/planum-magazine/learning-and-teaching-experiences/learning-by-design; accessed 29 December 2016.

Lynch, K. (1972). What time is this place?. Cambridge Mass.-London: The MIT Press.

Mareggi, M. (20I I). Ritmi urbani. Rimini: Maggioli.

Mareggi, M. (2012). Urban rhythms in the contemporary city. In D. Henkel et al. (eds.), Space-Time Design of the Public City, London-New York: Springer, pp. 3-20.

Mareggi, M. and Pucci P. (20I3). Designing open spaces in a valley. Rimini: Maggioli.

Martinotti, G. (1993). Metropoli. Bologna: II Mulino.

Mininni, M.V. (20I0). La costa obliqua. Un atlante per la Puglia. Turin: Donzelli.

Munarin, S. and Tosi M.C. (200I). Tracce di città. Milan: Angeli.

Munarin, S. and Tosi M.C. (2009). "Welfare space in Europe”. In 4th International Conference of the International Forum on Urbanism (IFoU). The new urban question. Urbanism beyond neo-liberalism. Amsterdam/Delft, available at: newurbanquestion.ifou.org/proceedings/3\%20The\%20Urbanized\%20Society/full\%20articles/D042_T OSI_MARIACHIARA_THE\%20WELFARE\%20SPACE\%20IN\%20EUROPE.pdf; accessed 29 December 2016.

Nuvolati, G. (2003). "Resident and Non-resident Populations: Quality of Life, Mobility and Time Policies”. In The Journal of Regional Analysis \& Policy. 33 (2): 67-83, available at: http://www.jrapjournal.org/pastvolumes/2000/v33/33-2-4.pdf; accessed 29 December 2016.

Nuvolati, G. (2007). Mobilità quotidiana e complessità urbana. Florence: University Press.

Officina Welfare Space (20I2) (ed.). Spazi del welfare. Esperienze luoghi pratiche. Macerata: Quodlibet.

Pasqui, G. (2008). Città, popolazioni, politiche. Milan: Jaca Book.

Pucci, P., Manfredini, F. and Tagliolato P. (20I5). Mapping urban practices through mobile phone data.

London: Springer.

Pulselli, R.M. and Romano P. (2009). Urban systems dynamics. Florence: Aliena.

Ratti, C., Pulselli, R.M., Williams, S. and Frenchman D. (2006). "Mobile landscapes: using location data from cell phones for urban analysis”. In Environ Plan. 33, pp. 727-748.

Secchi, B. (1986). "Projects for the ground”. In Casabella. 520, pp. 19-23.

Secchi, B. (1994). “Resoconto di una ricerca”. In Urbanistica. 103, pp. 25-30.

Secchi, B. (1999). "Un progetto per la città contemporanea”. In Cru. Critica della razionalità urbanistica. II-I2, pp. 52-6I.

Secchi, B. (2006). Progetto di suolo 2. In A. Aymonino and P.V. Mosco (eds.), Spazi pubblici contemporanei. Architettura a volume zero, Milan: Skira, Pp. 287-29I.

Sen, A. (1993). Capabilities and Well-Being. In M. Nussbaum and A. Sen (eds.), The Quality of Life, Oxford: Clarendon Press, pp. 30-53.

Simeoforidis, Y. (2002). Territori in transizione. In P. Ciorra and G. Mastrigli (eds.), La metropoli dopo, Rome: Meltemi, Pp. I50-167.

Soja, E. (1996). Thirdspace: Journeys to Los Angeles and Other Real-and-Imagined Places. Oxford: Blackwell. Whyte, W. (1980). The social life of small urban spaces. Washington, D.C.: Conservation Foundation. Zanettichini, L. (20II). Descrizione spazio-temporale della città e delle pratiche d'uso. Mappa on/off del centro di Cologno Monzese, unpublished. 